\section{DIGITAL COMMONS \\ @ UNIVERSITY OF SOUTH FLORIDA}

\section{Suburban Sustainability}

\title{
Sustainable Development for People or Profit?
}

\author{
Eric RR Weaver \\ University of South Florida, eweaver@usf.edu
}

Follow this and additional works at: https://digitalcommons.usf.edu/subsust

Part of the Agribusiness Commons, Agricultural and Resource Economics Commons, and the Civil and Environmental Engineering Commons

\section{Recommended Citation}

Weaver, Eric RR (2015) "Sustainable Development for People or Profit?," Suburban Sustainability: Vol. 3 : Iss. 1 , Article 2. http://dx.doi.org/10.5038/2164-0866.3.1.1019

Available at: https://digitalcommons.usf.edu/subsust/vol3/iss1/2

This Article is brought to you for free and open access by the Open Access Journals at Digital Commons @ University of South Florida. It has been accepted for inclusion in Suburban Sustainability by an authorized editor of Digital Commons @ University of South Florida. For more information, please contact digitalcommons@usf.edu. 


\section{Sustainable Development for People or Profit?}

\section{Cover Page Footnote}

I would like to acknowledge Dr. John Jermier for his continued support, professional direction, and outstanding commitment to helping me become a contributor to the scholarly field of sustainable development. Further, gratitude goes to the two blind reviewers and Marian Conklin for her document editing prowess. 


\section{Sustainable Development: for People or Profit?}

\section{Introduction}

Sustainability has made steady progress, according to the 2000 United Nations Conference on Sustainable Development (RIO+20), since 1987 when the Brundtland Commission released its "Report of the World Commission on the Environment and Development: Our Common Future." This work included agreements by world leaders to address human impact on the environment (United Nations 1992a), climate change, desertification and biodiversity (United Nations 1992b), policy implementation plans (United Nations 2002), and food production (G8 Summit 2009). However, these policies did not translate into action, leading scientists prior to the first Earth Summit in 1992 to request global political leaders to commit to actions beyond additional policy agreements, and discussions to address environmental degradation ${ }^{1}$

Research defined how environmental degradation continues to impact planetary systems (Rockström et al. 2009a). Again, before the June 2012 Rio+20 Earth Summit, scientists made recommendations to the world's political leaders for decisive actions against the environmental degradation problems (Biermann et al. 2012, UNEP 2012, Hansen, Sato, and Ruedy 2012, Barnosky et al. 2012). Here we show that although scientists consistently "cry wolf" for enforced environmental regulations and critical actions, the politicians have their own agenda and thus do not listen to scientists' recommendations (Hansen et al. 2012).

Building a sustainable alternative is required before any population can comprehend and undertake the required actions to support Earth's carrying capacity into the $22^{\text {nd }}$ Century, according to Leach et al. (2012). Leach argues that we find that the "status quo" (IAASTD 2009) paradigm of industrial agriculture systems is the primary factor impacting our planet's ecosystem. Population support for new agricultural alternatives must begin with recognizing that this "status quo" (IAASTD 2009) is about corporations and politicians maintaining their profits, not sustaining the planet, supporting the Earth's carrying capacity, or creating sustainable food security for any population ${ }^{2}$. "Business as usual is no longer an option" (IAASTD 2009).

Thus, here we show the major threat to sustainable agricultural systems and the Earth's carrying capacity is not only global warming, water shortages, and biodiversity loss; the existing sustainable agricultural systems are threatened most by industrial agriculture and the associated corporate land grabs (Cotula and

\footnotetext{
${ }^{1}$ Statement by the Royal Society and National Academy of Sciences (1992), Union of Concerned Scientists (1992), Watson (1992), Holden (1992), Stern (1993), Hansen et al. (1991).

${ }^{2}$ Monsanto Company. "Improving Agriculture" entry. Company website. 2002-2013. Retrieved Sunday, 12/16/2012. http://www.monsanto.com/improvingagriculture/pages/our-role.aspx
} 
Vermeulen 2009, ETC Group 2009, Gall 2003a, b, Ayres 2004), toxic over spray (Horrigan, Lawrence, and Walker 2002, Carson 1962, Davidson, Shaffer, and Jennings 2002, Jamison et al. 2006, Lindley 1976) and GMO drift (IAASTD 2009, Horrigan, Lawrence, and Walker 2002).

\section{Unsustainable industrial agriculture}

Industrial agriculture is the primary reason for human-provoked planetary impacts. Unsustainable industrial agricultural systems impact all the planetary systems defined by Rockström et al. (2009a) in research at the Stockholm Resilience Centre. Industry's unrelenting environmental degradation has impacted the Planetary Boundaries and threatens Earth's carrying capacity (Cohen 1995) for fundamental sustenance of all human populations. As shown in Figure 1, the original work of Rockström et al. (2009b) was so profound that it was highlighted in the top tier journal Nature. Similarly, articles to support this current debate were compiled from comparable top tier journals and references derived therein. The next section details the increased human-provoked impacts resulting from industrial agriculture in seven of these nine planetary systems studied in top tier journals.

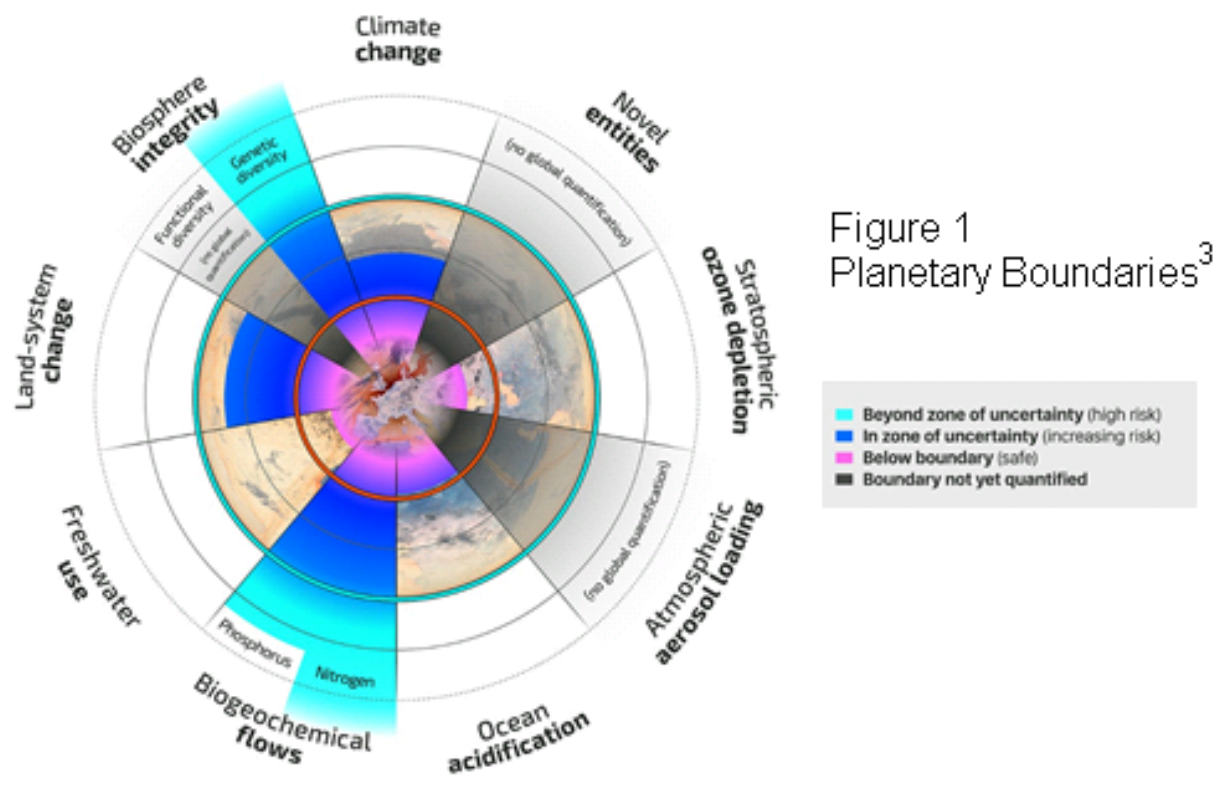

\footnotetext{
${ }^{3}$ The "safe operating space" indicated by the red circle for maintaining the planet's environment is based on nine critical system thresholds for Earth's sustainability. The blue identified areas exceed these scientifically determined limits (Félix Pharand-Deschênes, www.globaia.org, www.anthropocene.info, Used with permission).
} 


\section{Biodiversity loss}

The current industrial agricultural system causes loss of biodiversity according to Altieri (1999), Tscharntke et al. (2005), Chapin III et al. (2000), Ehrlich and Wilson (1991), and Davidson, Shaffer, and Jennings (2002). Tscharntke et al explain that industrial agriculture is a major threat to biodiversity globally, since such large areas of landscape are impacted by agriculture and further note that, as agrochemical use increased after World War II in Europe, cereal yields also increased, but with the simultaneous decline of bird populations. For example, Hole et al. (2005) and Krebs et al. (1999) noted that industrial agricultural is the "principal cause of the widespread declines in European farmland bird populations (e.g. Donald et al., 2001a; Krebs et al., 1999) and reductions in abundance and diversity of a host of plant and invertebrate taxa (e.g. Donald, 1998; Preston et al., 2002; Wilson et al., 1999) over the past four decades" (114).

Davidson, Shaffer, and Jennings (2002) found that four out of five California amphibians were impacted by upwind agricultural uses of agrochemicals, causing population declines as "exposure to pesticides may weaken immune systems, increasing susceptibility to disease" (1599). Ehrlich and Wilson (1991) reviewed three primary reasons to support biodiversity, beginning with the obvious: aesthetic and ethical reasons as a fundamental moral responsibility, then moving on to the considerable economic benefits that include industrial products, food, and medicines derived from biodiversity. Thirdly, and most critical, they point to the ecosystem services of biodiversity that maintain the oxygen composition of the atmosphere, biodegrade materials to create soils, and support other functions fundamental for food production.

MacDonald and Nierenberg (2003) estimated that a healthy global ecosystem provides services such as insects that pollinate crops, and healthy, soilcleansed water that help to avoid costs to society of nearly $\$ 61$ trillion. Chapin III et al. (2000) state that the current extinction rates are nearly 100-1,000 times greater now than before people became dominant on Earth. They give further detail about how interaction of species supports key resources within the environment that are important for a sustained planet (Figure 2). 
Figure 2 The Role of Biodiversity in Global Change ${ }^{4}$

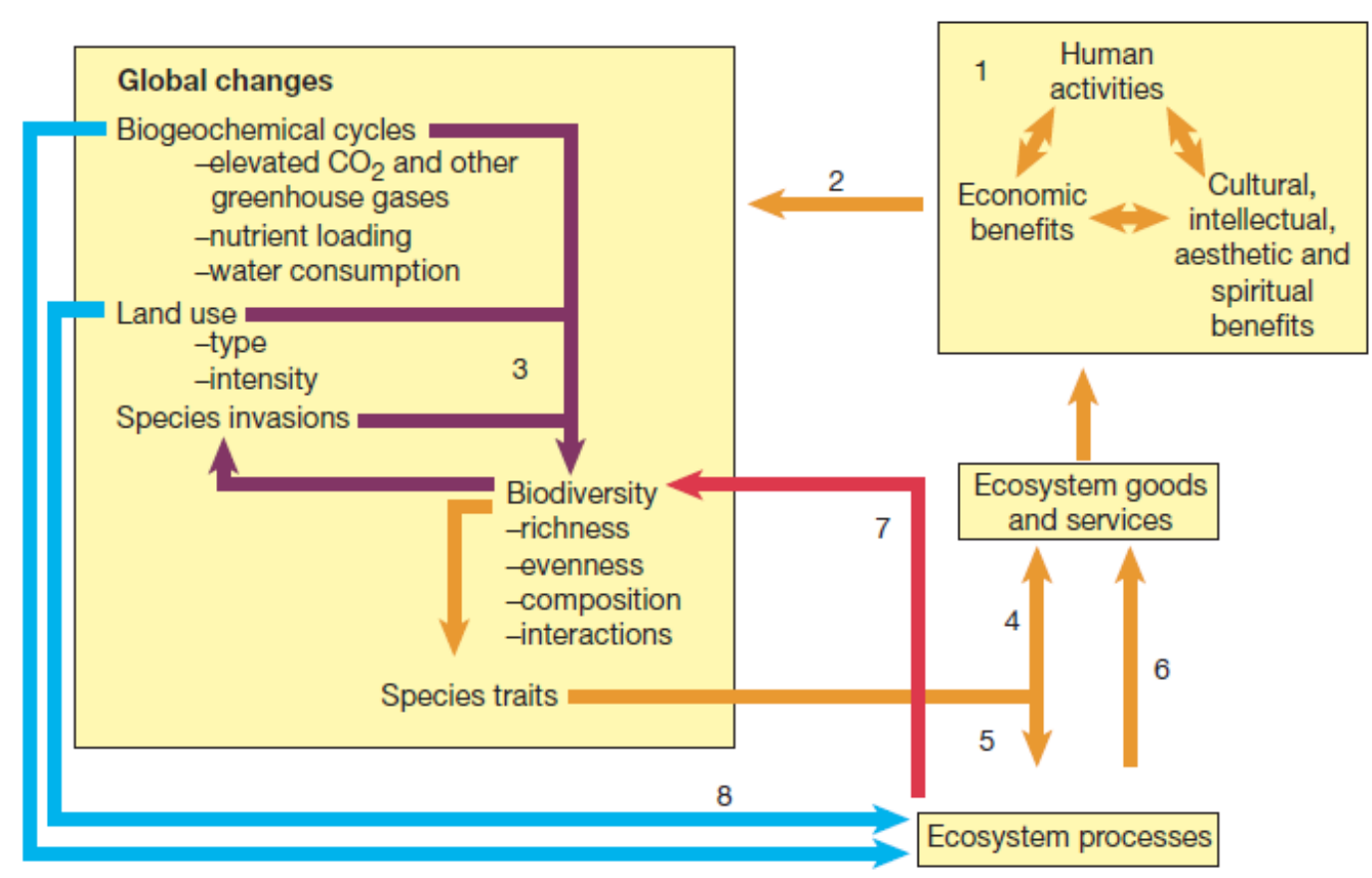

Similarly, Renner (2012) estimates that "52 percent of commercial fish stocks are fully exploited, about 20 percent are overexploited, and 8 percent are depleted" (5). Further, Myers and Worm (2003) noted that the "status quo" in industrialized fishing has consumed $90 \%$ of the global large predatory fish, while similar studies have identified a multitude of fisheries that have been overexploited or collapsed (see Table 1). For example, MacDonald and Nierenberg (2003) noted "over fishing caused the collapse of cod stocks off

\footnotetext{
4 "Human activities that are motivated by economic, cultural, intellectual, aesthetic and spiritual goals (1) are now causing environmental and ecological changes of global significance (2). By a variety of mechanisms, these global changes contribute to changing biodiversity, and changing biodiversity feeds back on susceptibility to species invasions (3, purple arrows; see text). Changes in biodiversity, through changes in species traits, can have direct consequences for ecosystem services and, as a result, human economic and social activities (4). In addition, changes in biodiversity can influence ecosystem processes (5). Altered ecosystem processes can thereby influence ecosystem services that benefit humanity (6) and feedback to further alter biodiversity (7, red arrow). Global changes may also directly affect ecosystem processes ( 8 , blue arrows). Depending on the circumstances, the direct effects of global change may be either stronger or weaker than effects mediated by changes in diversity. We argue that the costs of loss of biotic diversity, although traditionally considered to be 'outside the box' of human welfare, must be recognized in our accounting of the costs and benefits of human activities" (Quoted in Chapin, et al., 2002). Used with permission)..
} 
Canada's coast in the early 1990s, it threw 30,000 people out of work and decimated the economies of 700 communities in Newfoundland" (42). Of critical concern in more recent research, Worm et al. (2006) estimated all currently harvested species will similarly collapse by 2048, further reducing Earth's carrying capacity as supported by Table 1 .

Table 1 Collapsed Fisheries ${ }^{5}$

Authors

Concern areas

Journal

\begin{tabular}{|c|c|c|}
\hline $\begin{array}{l}\text { AH Altieri, MD Bertness, } \\
\text { TC Coverdale, NC } \\
\text { Herrmann (2012) }\end{array}$ & $\begin{array}{l}\text { collapse of a growing } \\
\text { number of shallow-water } \\
\text { marine ecosystem }\end{array}$ & Ecology, 93(6), 1402-1410 \\
\hline $\begin{array}{l}\text { TR Johnson, JA Wilson, C } \\
\text { Cleaver (2012) }\end{array}$ & $\begin{array}{l}\text { collapse of the Sea Urchin } \\
\text { Fishery in Maine, USA }\end{array}$ & $\begin{array}{l}\text { Ecology and Society, 17(2), } \\
15 .\end{array}$ \\
\hline W Li (2012) & $\begin{array}{l}\text { fishery collapse with two } \\
\text { periods analysis in Dong } \\
\text { Jiang Lake }\end{array}$ & $\begin{array}{l}\text { Journal of Agricultural } \\
\text { Science, } 4(7), 172\end{array}$ \\
\hline $\begin{array}{l}\text { Henderson, Peter A.; } \\
\text { Plenty, Shaun J.; Newton, } \\
\text { Lyn C.; et al. (2012) }\end{array}$ & $\begin{array}{l}\text { collapse of European eel } \\
\text { (Anguilla anguilla) in the } \\
\text { Bristol Channel }\end{array}$ & $\begin{array}{l}\text { Journal of the Marine } \\
\text { Biological Association, } \\
92(4), 843-85\end{array}$ \\
\hline $\begin{array}{l}\text { Zwolinski, Juan P.; Demer, } \\
\text { David A. (2012) }\end{array}$ & $\begin{array}{l}\text { forecasts a collapse of the } \\
\text { sardine stock }\end{array}$ & $\begin{array}{l}\text { Proceedings of the Nationa } \\
\text { Academy of Sciences, } \\
109(11), 4175-4180\end{array}$ \\
\hline $\begin{array}{l}\text { Downing, Andrea S.; van } \\
\text { Nes, Egbert H.; Janse, Jan } \\
\text { H.; et al. (2012) }\end{array}$ & $\begin{array}{l}\text { collapse and reorganization } \\
\text { of a food web of Mwanza } \\
\text { Gulf, Lake Victoria }\end{array}$ & $\begin{array}{l}\text { Ecological Applications, } \\
22(1), 229-23\end{array}$ \\
\hline $\begin{array}{l}\text { Chapman, Demian D.; } \\
\text { Simpfendorfer, Colin A.; } \\
\text { Wiley, Tonya R.; et al. } \\
\text { (2012) }\end{array}$ & $\begin{array}{l}\text { collapse in a critically } \\
\text { endangered marine fish: the } \\
\text { Smalltooth Sawfish (Pristis } \\
\text { pectinata) }\end{array}$ & $\begin{array}{l}\text { Journal of Heredity, } \\
102(6), 643-652\end{array}$ \\
\hline
\end{tabular}

\section{Nitrogen and phosphorus cycles}

The "status quo" of industrialized agriculture includes fertilizers as a major culprit in global warming and water body eutrophication (Fedoroff et al. 2010, Bennett, Carpenter, and Caraco 2001, Arbuckle and Downing 2001, Bright 2003). For example, Arbuckle and Downing (2001) completed a detailed study of agricultural lands in Iowa including 113 lakes to find significant nitrogen and phosphorus concentrations associated with row crop industrial agriculture practices. Bennett, Carpenter, and Caraco (2001) estimated that Earth's water

${ }^{5}$ World of Knowledge database search for the topic "collapse \& fish" yielded 243 articles. Table 1 represents a random sample of these articles, all completed by different authors and from different journals in various locations. 
systems have $75 \%$ greater amounts of phosphorus than in the preindustrial times. This over enrichment results in eutrophication causing algae blooms, which deplete oxygen, kill fish, reduce biodiversity, and increase toxins making water undrinkable. He continued this analysis to state that "clearly, $\mathrm{P}$ [phosphorus] is accumulating in Earth's surface soils, primarily in agricultural areas" (Bennett, Carpenter, and Caraco 2001, 231). More specifically, Fedoroff et al. (2010) noted that "nitrogenous compounds in fertilizers are major contributors to waterway eutrophication and greenhouse gas emissions" (833). Bright (2003) estimates that people have doubled the release of nitrogen to nearly 350 million tons per year while phosphorus delivery is 3.7 times the natural rate of 13 million tons per year.

\section{Change in land use}

Industrial agriculture impacts on land use, be it from deforestation or typical agricultural practices, have significantly increased the loss of soil (Pimentel et al. 1995, Montgomery 2007, Brown 2011a, Turner and Rabalais 2003). Montgomery (2007) detailed how the global data confirms the fact that agricultural practices result in twice as much soil loss from erosion than from soil production. Turner and Rabalais (2003) referred to the work of the Iowa State Planning Commission in 1948 (cited in Prince 1997) stating that "disturbance of the state's prairie had caused the loss of 192,643 metric tons per $\mathrm{km}^{2}$ of soil and that $40 \%$ of Iowa had lost $50 \%$ to $75 \%$ of its surface soil" (566).

More specifically, they stated that agriculture as late as 1780: "On this continent, the cheap and unlimited land[,] promoted a widespread attitude that land could be used, exhausted, or destroyed as the case may be, and then abandoned for new land" (Turner and Rabalais 2003, 566). This practice is fundamental to the ways that multinational industrial processes create profits through exploitation of the global commons. Brown (2011a) argues that the health of the population cannot be separated from the health of the soil and specifically quantifies this, claiming that "for each inch of topsoil lost, wheat and corn yields declined by close to 6\%" (26). Pimentel et al. (1995) took this one step further with an analysis of corn farming expenses, breaking it down to the economic and energy costs required by the agricultural industry to replace the loss of soils (see Table 2), which converts to a total of $\$ 27$ billion per year in the US alone. 
Table 2 Estimated annual economic and energetic costs (per hectare) of soil and water loss ${ }^{6}$

\begin{tabular}{lcccc}
\hline Factors & $\begin{array}{c}\text { Annual } \\
\text { quantities } \\
\text { lost }\end{array}$ & $\begin{array}{c}\text { Cost of } \\
\text { replacement } \\
\text { (dollars) }\end{array}$ & $\begin{array}{c}\text { Energetic } \\
\text { costs } \\
\left(10^{3} \mathrm{kcal}\right)\end{array}$ & $\begin{array}{c}\text { Yield loss after 20 } \\
\text { years of erosion } \\
(\%)\end{array}$ \\
\hline $\begin{array}{l}\text { Water runoff } \\
\text { Nitrogen }\end{array}$ & $75 \mathrm{~mm}$ & 30 & 700 & 7 \\
Phosphorus & $50 \mathrm{~kg}$ & & 500 & 8 \\
Potassium & $2 \mathrm{~kg}$ & 100 & 3 & 7 \\
Soil depth & $410 \mathrm{~kg}$ & & 260 & 4 \\
Organic matter & $1.4 \mathrm{~mm}$ & 16 & - & 2 \\
Water holding capacity & $2 \mathrm{tons}$ & - & - & 1 \\
Soil biota & $0.1 \mathrm{~mm}$ & - & - & 20 \\
Total on-site & - & - & 1460 & \\
Total off-site & & 146 & 100 & \\
Grand total & & 50 & 1560 & \\
\hline
\end{tabular}

Further, Brown (2011b) provides extensive details about the global impacts of industrial agriculture on Earth's carrying capacity. This includes a specific review of the impacts on the soil, air, and waters of Earth. For example, the issues of soil erosion and desertification have reached critical proportions internationally, where "desertification now affects 25 percent of Earth's land area. And it threatens the livelihoods of more than 1 billion people - the families of farmers and herders in roughly 100 countries" (Brown 2011b, 37). The plant life of Earth protects the soil from wind and water erosion, while the increase of industrial agriculture techniques of meat herd over-grazing, crop area overplowing, and forest clear-cutting remove this important plant life leaving the soil bare for erosion and further desertification.

\section{Water pollution}

Industrial agriculture is a major cause of the world's water pollution (Turner and Rabalais 2003, Mallin 2000, Kennedy and Worcester 2004, Kirby 2010, MacDonald 2012, Mikhail 2012, Horrigan, Lawrence, and Walker 2002). Factory farms now concentrate manure in adjacent lagoons. This changed the ecological manure, which supported previous generations' family farms, into toxic waste,

\footnotetext{
${ }^{6}$ These values are from conventional corn, assuming the current water and wind erosion rate of 17 tons ha-1 year-1 over the long term (20 years). Adopted from Pimentel, D., Harvey, C., Resosudarmo, P., Sinclair, K., Kurz, D., McNair, M., .. . Blair, R. "Environmental and economic costs of soil erosion and conservation benefits." 1995. Science, 267(5201), (1119). (Used with permission.)
} 
impacting water supplies. Research in this area has shown that "US animal factories yield 100 times more waste than all US human sewage plants" (Kirby 2010). For example, on June 22, 199525 million gallons of swine waste leaked into the New River, on July 3, nine million gallons of poultry waste spilled into Limestone Creek, and on August 8 of the same year, one million gallons of swine waste into Harris Creek, NC. All of this occurred before hurricanes Fran and Bonnie flooded these areas the following year (Mallin 2000). Kennedy and Worcester (2004) details this tragedy of Concentrated Animal Feeding Operation in North Carolina by finding that "there are many studies that show that factory farms have a devastating impact on rural economies and quality of life. There is not a single empirical study showing net benefits to rural communities" (51). They continue explaining below:

Pig factories produce far more manure than is needed to fertilize the fields around them. The costs of properly treating and disposing of this waste make factory farming uncompetitive for traditional farms - unless they violate numerous environmental laws. Because factory meat producers must break the law in order to survive, the industry's business plan relies on the assumption that pork factories will be able to evade prosecution by improperly influencing government officials (Kennedy and Worcester 2004, 52) The industry routinely uses bullying lawyers and illegal intimidation, threats, harassment and violence to terrorize and silence its critics (53).

Kirby (2010) also noted, "Human sewage is treated to kill pathogens but animal waste is not. Hog manure has 10-to-100 times more pathogens than human waste." Similarly, China's livestock generates 2.7 billion tons of manure (MacDonald 2012). Further, fertilizer and pesticides applied to farming areas leach into groundwater and surface waters (Mikhail 2012). Turner and Rabalais (2003) summarize the many studies, which define the agricultural application of fertilizer to be the primary source of increased nutrient loadings in major rivers and estuary systems. Their review of the 1,151,000 square mile Mississippi River Basin, which drains the 14 state industrial agriculture region of the US "breadbasket," had $40 \%$ of the rivers listed as "impaired" by EPA in 2000. The river impact resulted in a nearly 8,000 square mile dead zone in the Gulf of Mexico. Further, this impact resulted from exceeding a tipping point mentioned earlier by Rockström et al. (2009b) such that "when the atomic ratio of silicate to nitrate falls below 1:1, the food web off the Mississippi River seems to switch from a diatom based ecosystem to another ecosystem state that may be less desirable" (Turner and Rabalais 2003, 570). Further, Horrigan, Lawrence, and Walker (2002) accounts that the EPA "has blamed current farming practices for $70 \%$ of the pollution in the nation's rivers and streams. The agency reports that 
runoff of chemicals, silt, and animal waste from U.S. farmland has polluted more than 173,000 miles of waterways" (447). Additionally, Frommel et al. (2012) claimed that "Ocean acidification, caused by increasing atmospheric concentrations of $\mathrm{CO}_{2}$, is one of the most critical anthropogenic threats to marine life" (42).

\section{Water Use}

Industrial agriculture contributes significantly to global water shortages (Gleick 2000, Mikhail 2012, Horrigan, Lawrence, and Walker 2002). Mikhail (2012) estimated that $70 \%$ of global freshwater is used for agriculture, dropping water tables, and causing saltwater intrusion. Horrigan, Lawrence, and Walker (2002) had determined that one-third of the agricultural food production came from irrigated lands as depicted in Figure 3.

Figure 3 Global water use by industry $\left(10^{\wedge} 9 \mathrm{~m} 3 / \mathrm{yr}\right)^{7}$

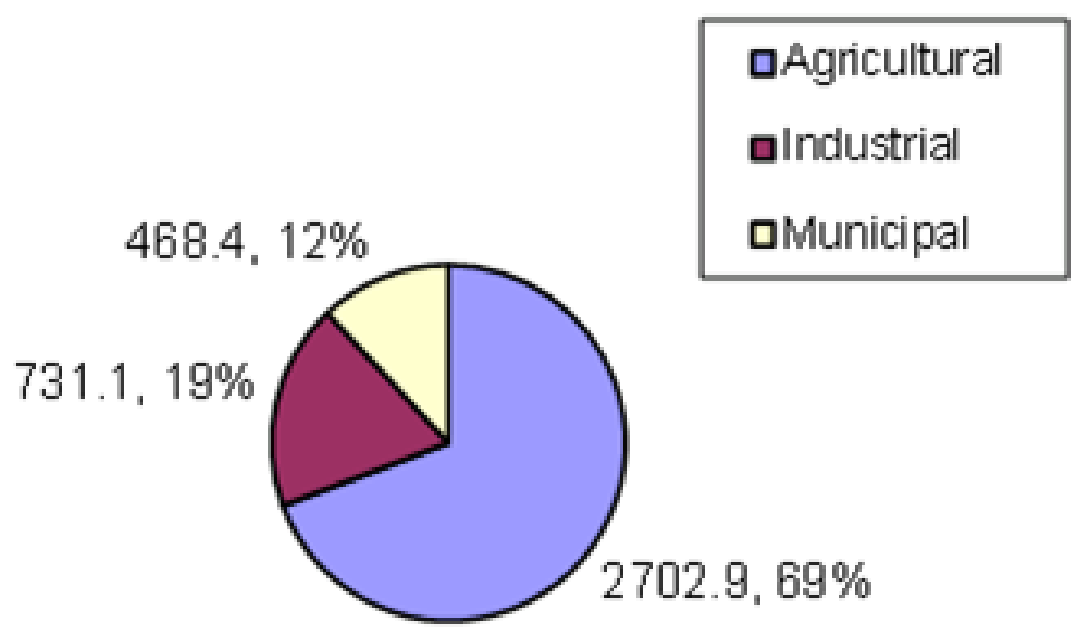

Gleick (2000) estimated this water was used to irrigate nearly 267 million hectares in 2000, nearly seven times as much as in 1900 as depicted in Figure 4. However, he also noted that nearly $40 \%$ of this water is lost through leaky pipes and overspray.

\footnotetext{
${ }^{7}$ Data compiled from values: FAO. 2015. AQUASTAT database, Food and Agriculture Organization of the United Nations (FAO). Website accessed on 10/05/2015 http://www.fao.org/nr/water/aquastat/main/index.stm.
} 
Figure 4 World populations, water use and irrigation areas ${ }^{8}$

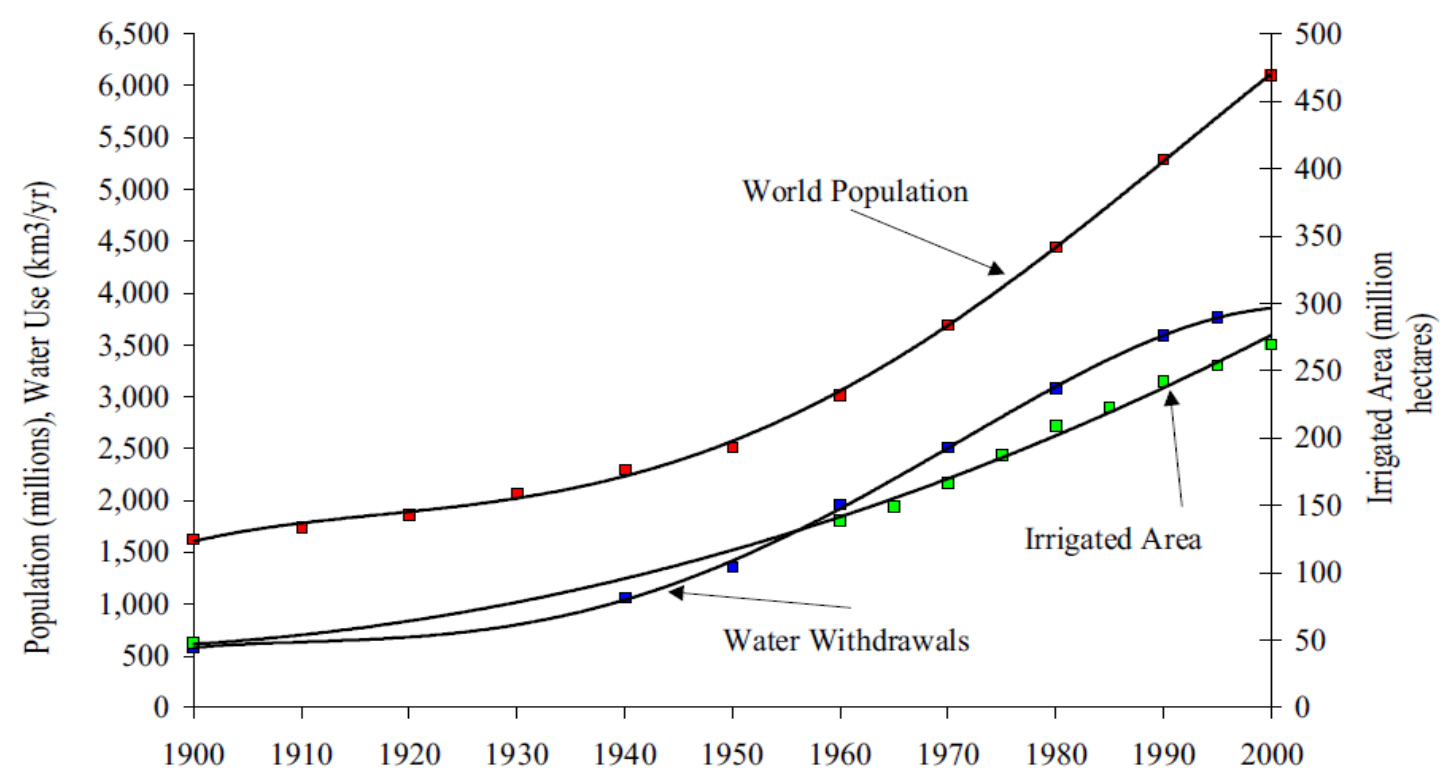

\section{Chemical pollution}

Beyond water pollutions mentioned earlier, GMO and industrial marine agriculture result in significant impacts, including water pollution, benthic pollution, herbicides, antibiotics, and other pesticide chemicals accumulating in the ecosystems (Klinger and Naylor 2012, McGinn 2002, Spinks 2011). McGinn (2002) noted "farmers worldwide will apply something on the order of 2.5 million tons of pesticides, the over whelming majority of which are synthetic organic chemicals that are orders of magnitude more toxic than 50 years ago" (77). Horrigan, Lawrence, and Walker (2002) estimated this impact is closer to 3 million tons per year, including herbicides, insecticides, and fungicides; only $0.1 \%$ of these chemicals are effective for crops, while $99.9 \%$ impact the surrounding environment. Benbrook (2012) determined that in the US alone, the planting of GMO crops, promoted with claims it would "decrease the overall use of herbicides," 9 has resulted in a 527 million pound increase in herbicides from 1996-2011. He further estimated that the new 2,4-D GMO brands proposed for

\footnotetext{
${ }^{8}$ Adopted from Gleick, P. H. 2000. "The changing water paradigm: a look at twenty-first century water resources development." Water International, 25(1), (128) (used with permission).

${ }^{9}$ Existing website quote "Their use on Roundup Ready crops has allowed farmers to conserve fuel, reduce tillage and decrease the overall use of herbicides." Monsanto Company, "Agricultural Herbicides." Web. 2015. Retrieved 12/16/2012 http://www.monsanto.com/products/Pages/agricultural-herbicides.aspx
} 
USDA approval to avert the new herbicide resistant super-weeds will result in another 50\% increase in herbicide use. Simultaneously, since 2002 the multinational industrial agriculture company Monsanto has had a 1,047\% increase in stock values. ${ }^{10}$

Elsewhere, the multinational industrial agriculture development in India has impacted the carrying capacity there, including hundreds of suicides related to GMO expansions. The "government statistics estimate that as many as 250,000 farmers have committed suicide after failed cotton harvests left them saddled with debt" (Spinks 2011). The official Minister of Environment and Forests, Jairam Ramesh, introduced an indefinite moratorium on Bt brinjal, in February 2010 (Jayaraman 2010). These were significant steps to address the continued civil violations and public outcry against the multinational industrial agriculture "status quo" expansion in India.

However, the multinational lobby responded by changing the laws to circumvent this decision through the Biotechnology Regulatory Authority of India Bill, 2011 (BRAI, Bill No 54 2011). One researcher described this new bill, promoted by the industrial agriculture lobby, as an attempt to "ensure that India becomes a safe haven for large firms to run their tests and sell their [GMO] products" (Tanmay 2011, 13). This position coincides with the evaluation by the Coalition for a GM-Free India who reported that the BRAI Bill had the wrong mandate of promoting [GMO] corporations into self-regulators (Coalition for a GM-Free India 2012). Subsequently, the Indian government filed a lawsuit against Mahyco-Monsanto Biotech Limited for their "'unlawful' attempt to obtain and modify the indigenous crop brinjal" to suspend the "status quo" industrial agriculture expansion into India and end these critical impacts on the Earth's carrying capacity (Spinks 2011, 1).

Industrialized agricultural systems also include the mining and processing of fertilizers, which are a major culprit in climate change and water body eutrophication (Arbuckle and Downing 2001, Bennett, Carpenter, and Caraco 2001, Bright 2003, Fedoroff et al. 2010). Thus, unsustainable industrial agricultural systems impact nearly all the planet's systems defined by Rockström et al. (2009a).

\section{Unsustainable policy development}

Despite the call for decisive actions, the Rio+20 Conference was a missed opportunity, where "[d]ismal grades dominate Nature's report cards on the Rio treaties" (Tollefson and Gilbert 2012). Gisbert Glaser, senior advisor at the

\footnotetext{
${ }^{10}$ Open price: 8.73 , Date: 11/29/2002 to Open: 91.83, Date: 11/29/2012. Monsanto Company, "Stock Performance" entry. Web. 2015. Retrieved 12/16/2012. http://www.monsanto.com/investors/Pages/stock-performance.aspx
} 
International Council for Science (ICSU), claimed the world's political leaders would only continue " 'development as usual,' rather than [take] action on the scale that the scientific evidence now demands" (Irwin 2012). The final 49-page document, The Future We Want (United Nations 2012), signed at the Rio+20 Conference, only delayed real action to maintain the "status quo" of existing industrial agriculture systems. Calls for small numbers of focused targets on sustainability development goals or any changes of the "economic playing field" (Griggs et al. 2013) are still falling on deaf ears.

The failure of the Rio+20 is better understood by comparing it to the success of the May 2012 G8 Camp David Summit, which resulted in the New Alliance for Food Security and Nutrition (Office of the Press Secretary 2012). The G8 Summit created a new partnership to support the multinational industrial agriculture expansion into Africa (Fig. 5), while none of these key global leaders attended the Rio+20 conference the following month.

Figure 5 Conference room during the G8 Summit at Camp David ${ }^{11}$

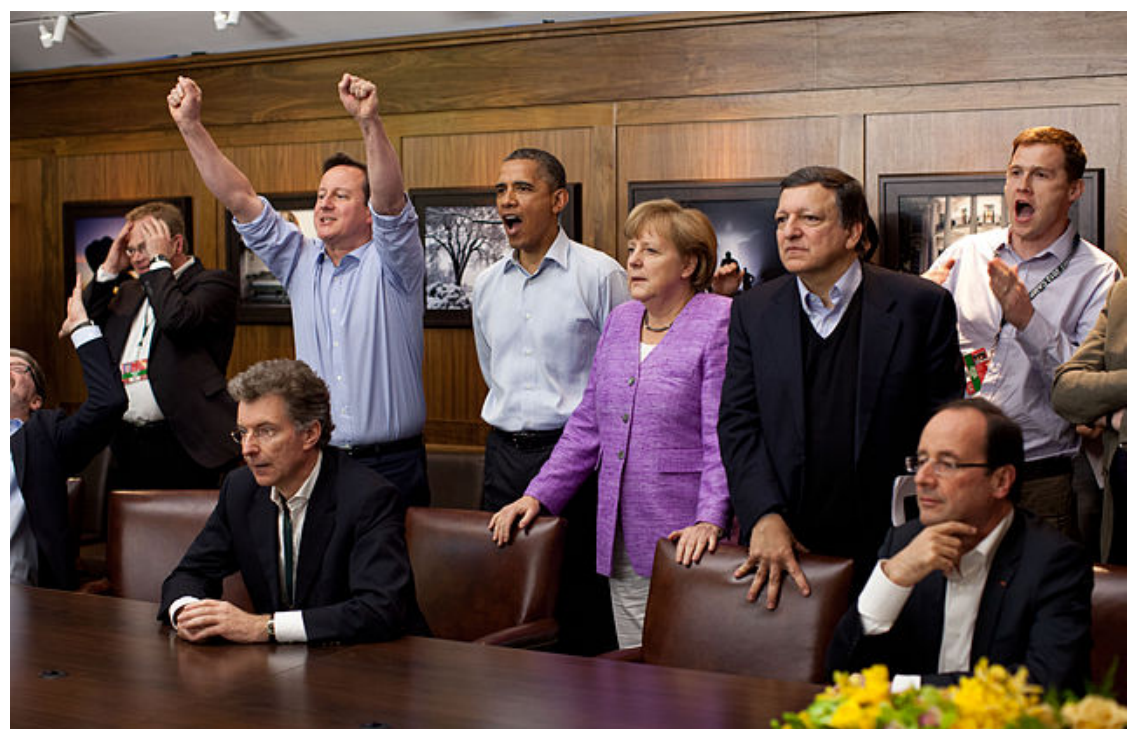

\footnotetext{
${ }^{11}$ Prime Minister David Cameron of the United Kingdom, President Barack Obama, Chancellor Angela Merkel of Germany, José Manuel Barroso, President of the European Commission, and others watch the overtime shootout of the Chelsea vs. Bayern Munich Champions League final, in the Laurel Cabin conference room during the G8 Summit at Camp David, Md., May 19, 2012. (Official White House Photo by Pete Souza)
} 
The G8 action confirms political leaders' desire to support the "status quo," as according to Holt Gimenez and Shattuck (2011), "corporations dominate the government agencies and multilateral organizations that make and enforce the regime's rules, regulations, and projects for trade, labor, property, and technology" (92). Further, scientists have noted the major political players and global food governance groups enforce the "status quo" and are "bureaucratic, slow to act and lack foresight" (von Braun 2010, 548) with regards to any change.

\section{Unsustainable corporate entanglement}

The public response to the G8 deal was non-existent while the public outcry after the closing of the 2012 Rio Summit addressed the lack of action. For example, the Centre for Environment and Development put forth the "Peoples' Sustainability Treaties" seeking to "transcend the parochial concerns of a corporate-capitalistic globalization" (Zoysa 2012). Similarly, the People's Action at the Earth Summit (Rio Occupy Working Groups 2012) requested the ending of the "corporate capture of the UN." The partnerships between private corporations and national officials continue to compromise the needs of the environment and the general population much as the G8 May 2012 deal only guaranteed multinational industrial agriculture development into Africa.

Dr. James Hansen, the retired Director of the NASA Goddard Institute for Space Studies in New York City, was more direct about the lack of political progress during a presentation to young people:

How is it possible that large human-driven climate change is unfolding virtually unimpeded, despite scientific understanding of likely consequences? Would not governments - presumably instituted for the protection of all citizens - have stepped in to safeguard the future of young people? A strong case can be made that the absence of effective leadership in most nations is related to the undue sway of special financial interests on government policies aided by pervasive public relations efforts by organizations that profit from the public's addiction to fossil fuels and wish to perpetuate that dependence (Hansen et al. 2012, 17).

Multinational corporations have invested in significant land and technological equipment to produce a profit and will maintain this initial capital investment as long as it continues to profit (Piketty and Goldhammer 2014). Climate change is one planetary system now better understood by global politicians and populations. On January 24, 2014, the UN Secretary-General Ban Ki-moon stated, "We need large injections of public capital for the rapid development of low-carbon infrastructure" (O'Reilly, Paper, and Marx 2012). 
These concerns stem from the latest Intergovernmental Panel on Climate Change (IPCC) scientific report which stated: "Warming of the climate system is unequivocal" (IPCC 2013, 62). However, multinational investment continues to support old technologies such as oil refineries (Klein 2014) and other capital intensive industries to maintain tremendous profits (Piketty and Saez 2014), similar to investments in the machinery of industrial agriculture (Vallianatos 2014). There is no need to explore solar or other new, healthier technologies (Marmot 2014), while these old investments are still profitable (Stehr 2014).

Correspondingly, global energy industries currently have coal, oil, and gas reserves for creating 2,795 gigatons of carbon dioxide emissions. Planetary simulation models indicate that the Earth's atmosphere can remain within a reasonable two degree change with only 565 gigatons of carbon dioxide by the mid- $21^{\text {st }}$ century (McKibben 2012). This is a planetary boundary limit defined by scientists, not by the banks or anyone with influence over multinational energy corporations and their profits. Thus, multinationals will continue to maximize profits at any cost, similar to NAFTA destroying subsistence farming in Mexico (Klein 2001), the western expansion's destruction of the indigenous people of Pine Ridge, South Dakota (Moyers and Hedges 2012). Clearly, the "class exploitation, imperialism, war, and ecological devastation are not mere unrelated accidents of history but interrelated, intrinsic features of capitalist development" as noted by Foster $(2007,2)$. Similarly, as Ghoshal (2005) surmised, industry intends to reduce Earth's carrying capacity through:

[... ] ruthlessly hard-driving, strictly top-down, command-and-control focused, shareholder-value-obsessed, win-at-any-cost business leader of which Scott Paper's "Chainsaw" Al Dunlap and Tyco's Dennis Kozlowski are only the most extreme examples. This is what Isaiah Berlin implied when he wrote about absurdities in theory leading to dehumanization (85).

The unsustainable industrial agriculture "status quo" systems are based on importing agro-chemicals, machinery, and technologies to prioritize profits in support of multinational corporations at the expense of the environment, rural communities, indigenous farmer knowledge, and biodiversity (Foster 2007, Altieri 1999, Alkon and Norgaard 2009, Altieri 2009, Kerr 2012, Altieri, Letourneau, and Davis 1983). The New Green Revolution proposed at the May 2012 G8 Camp David Summit with the Alliance for Food Security and Nutrition (Office of the Press Secretary 2012) seeks only to continue this industrial expansion of the "status quo," now including patented seeds with further immeasurable impacts on Earth's carrying capacity (Klein 2001, Howard 2009). However, GM crops tended to have no increased yields beyond the traditional breeding, improved irrigation, and indigenous agricultural practices (Gurian- 
Sherman 2009). These crops create significant issues, and as Horrigan, Lawrence, and Walker (2002) found "in the Philippines, Indonesia, and some other developing countries, more than $80 \%$ of farmers now plant modern rice varieties. In Indonesia, this led to the recent extinction of 1,500 local rice varieties in just 15 years" (448).

\section{Unsustainable population pressures}

The world population is likely to be over 10 billion by 2050 (Keilman 2001, Pearce 2011). To exacerbate this issue further, after 2005 this world population has become more urban than rural, where more people are migrating into cities and urban areas as depicted in Figure 6.

Figure 6 Current UN world population estimates ${ }^{12}$

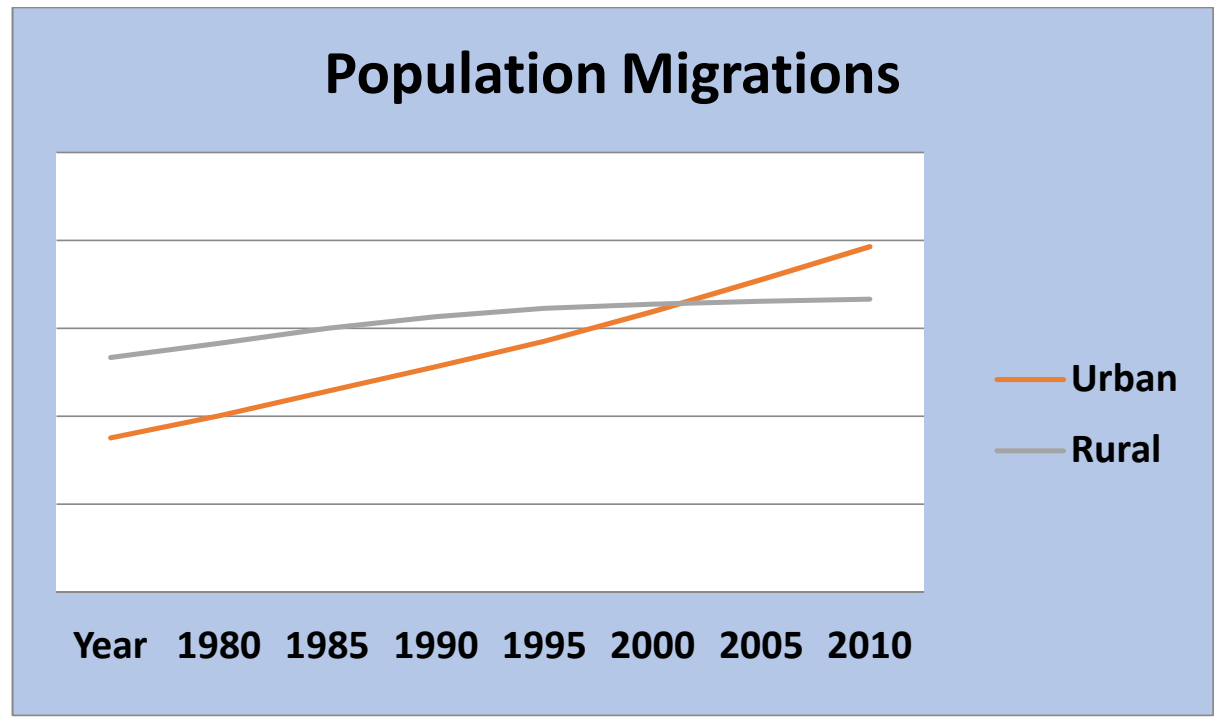

This increasing urban population is of serious concern, while the accompanying natural resource consumption and waste generation in urban areas is critical. Urban populations are expected to increase most rapidly in the less economically developed regions of the world. For example, in India the average population growth rate of $1.3 \%$ per year is higher than most regions in the world. Further, the urban population in India is growing at $2.5 \%$ per year. More critically, Chandrasekhar and Ghosh (2014) have noted that "The ratio of urban to rural consumption rose from 1.79 in 1983 to 1.96 in 2009-10, with the most rapid

\footnotetext{
${ }^{12}$ Estimates of the urban and rural population by age and sex, 1980-2015. Website accessed on 10/05/2015 http://esa.un.org/unpd/wpp/Excel-Data/population.htm.
} 
widening of the gap coming after 2004-05" (2). This disparity is demonstrated in Figure 7 , indicating the precarious issue is the excessive consumption in these expanding urban areas.

Figure 7 India's consumption disparity ${ }^{13}$

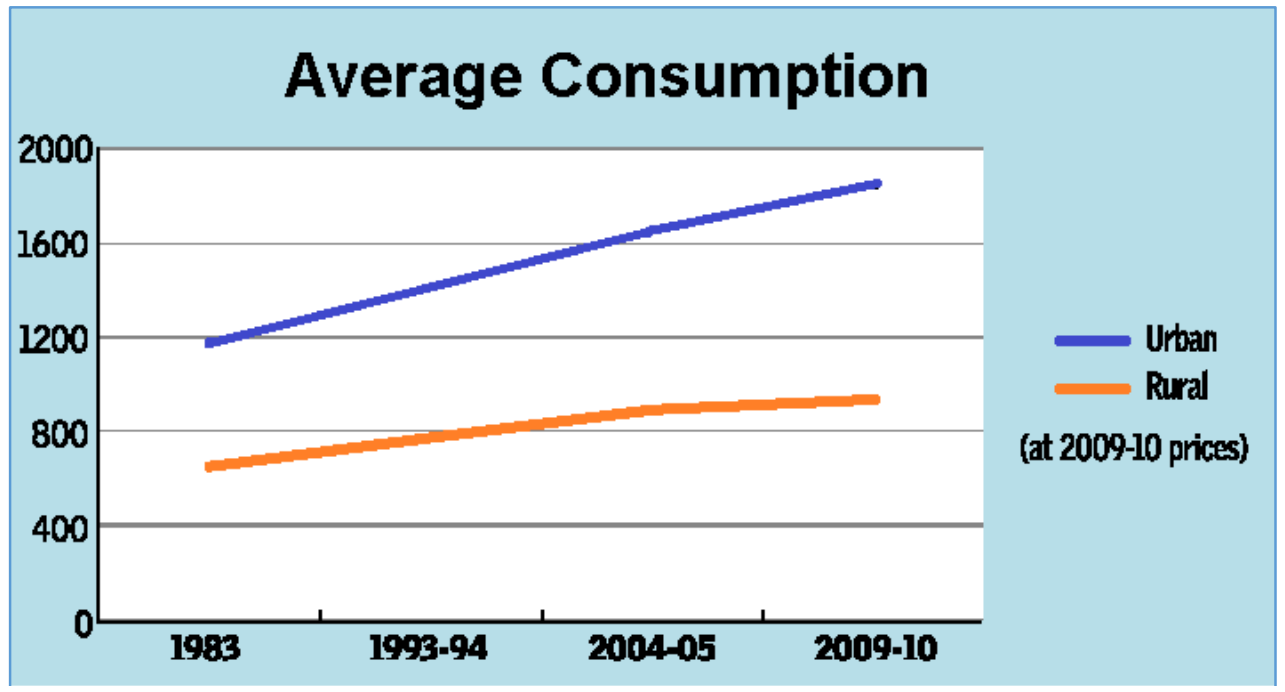

These high rates of natural resource consumption and waste generation forced critical environmental impacts to the forefront of scientific discourse. The Rockström et al. (2009b) treatise states that (if continued) these current environmental impacts to the "Earth System could destabilize critical biophysical systems and trigger abrupt environmental changes that would be catastrophic for humans" (2). Government regulations and global treaties have proven ineffective in reducing the environmental impacts of industrial agriculture as the planetary impacts outlined above indicate.

\section{Sustainable solutions}

"Fixing the dysfunctional food system - in any sustainable sense - requires regime change" (Holt Gimenez and Shattuck 2011, 93). Considerable sustainable agricultural systems have continued on Earth for thousands of years, essentially right under our collective noses. Altieri (1989) stated "Agroecology has emerged

\footnotetext{
${ }^{13}$ Estimates of urban and rural population consumption are adopted from Chandrasekhar, C.P., \& Ghosh, J. (2014). Consumption inequality in India. The Hindu Business Line. http://www.thehindubusinessline.com/opinion/columns/c-p-chandrasekhar/consumptioninequality-in-india/article3569657.ece
} 
as a scientific approach used to study, diagnose and propose alternative low-input management of Agroecosystems. Solving the sustainability problem of agriculture is the primary aim of Agroecology" (27). Altieri (1999) notes that contrary to industrial agriculture, biodiversity through agroecological systems can expand soil fertility, protect crops (without agrochemicals), and increase productivity naturally. Agroecological scientists have been investigating and researching the sustainable indigenous systems throughout Earth (Altieri, FunesMonzote, and Petersen 2012). This coincides with more recent calls from Leach et al. (2012) where the "fundamental challenge remains in more effectively connecting local, grassroots innovation capacity with the global parameters set by Planetary Boundaries."

As mentioned earlier, the multinational industrial agriculture model tried to obtain and modify the indigenous crop brinjal in India, resulting in lawsuits (Abdelgawad 2012). However, with the recent G8 Alliances, these same multinational corporations have been given free reign over vast areas of Africa to continue the same exploitive practices that ultimately degrade environmental resources, impoverish the native populations, and destroy existing indigenous practices and knowledge in return for quarterly profits to stockholders as discussed in India. This clearly demonstrates the "explicit denial of any role of moral or ethical considerations in the practice of management" (Ghoshal 2005, 79) by these multinational corporations.

We have seen how the multinational corporate lobby ensures (Sheets 2013) that the international regulatory focus is on providing monopoly support for creating exorbitant profits, such as Monsanto's 1,047\% increase in stock values. ${ }^{3}$ Thus, future research must focus on building a sustainable grassroots effort as recommended by Leach et al. (2012) combined with the agroecological sustainable knowledge as outlined by Altieri, Funes-Monzote, and Petersen (2012) to support an ideal solution contrary to industrial agriculture.

\section{Urban agriculture as sustainable agriculture}

Urban agriculture, shared amongst indigenous populations globally, is commonly understood as agriculture in urban areas. One underlying cause of urban agriculture is the global population increase. As indigenous people become displaced, they populate shantytowns adjacent to cities. Increasingly, these displaced people revert to agricultural traditions and create more urban agriculture (Altieri 2002). Thus, today urban agriculture has become a vital set of practices both for industrialized societies and for supporting food security in less developed countries and for urban refugees (Altieri 2009). Thus, urban agriculture represents a grassroots alternative to industrial agriculture. 
As mentioned previously with agroecology, many scientists (biologists, geologists, ecologists) and technical policy analysts (engineers, public administrators, and planners) have conducted systematic studies of urban agriculture and have developed rich descriptions of urban agriculture phenomena (Altieri 2005, De Schutter 2010, Rosset 2011). This work has produced numerous theoretical statements, quantitative and qualitative empirical studies, literature reviews, and conceptual critiques. Therefore, the next critical step in the development of the industry of urban agriculture is to establish scholarly research to determine the critical components for expanding and supporting urban agriculture as a sustainable development alternative in rapidly developing urban areas (De Schutter 2014).

\section{Conclusion}

Urban agriculture as a sustainable grassroots alternative could replace industrial agriculture (Piketty and Saez 2014). This action could create a paradigm shift to easily attainable healthy organic foods within an urban food desert. Such a system could be supported by a local community food cooperative linked to other local farmers, creating a suitable market (Donnell 2014). The local schooling facilities and community service institutions could be engaged to support community outreach for further development (De Schutter 2014). This results in an alternative urban agriculture paradigm (Teka, Van Rompaey, and Poesen 2013), which as noted by Ghoshal $(2005,87)$ "Thomas Kuhn (1962) was right in arguing that mere disconfirmation or challenge never dislodges a dominant paradigm; only a better alternative does." Critical questions future research must address include: How well can urban agriculture effectively reduce industrial agriculture? What measures for urban agriculture can be developed? How can urban residents be encouraged to support urban agriculture? How can urban agriculture bring a paradigm shift? 


\section{References}

Abdelgawad, By Walid. 2012. "TheBtBrinjal Case: The First Legal Action Against Monsanto and Its Indian Collaborators for Biopiracy." Biotechnology Law Report no. 31 (2):136-139. doi: http://dx.doi.org/10.1089/blr.2012.9926.

Alkon, A. H., and K. M. Norgaard. 2009. "Breaking the Food Chains: An Investigation of Food Justice Activism." Sociological Inquiry no. 79 (3):289-305. doi: http://dx.doi.org/10.1111/j.1475-682X.2009.00291.x.

Altieri, M. A. 1989. "Agroecology - a New Research and Development Paradigm for World Agriculture." Agriculture Ecosystems \& Environment no. 27 (14):37-46. doi: http://dx.doi.org/10.1016/0167-8809(89)90070-4.

Altieri, M. A. 1999. "The ecological role of biodiversity in agroecosystems." Agriculture Ecosystems \& Environment no. 74 (1-3):19-31. doi: http://dx.doi.org/10.1016/S0167-8809(99)00028-6.

Altieri, M. A. 2005. "The Myth of Coexistence: Why Transgenic Crops Are Not Compatible With Agroecologically Based Systems of Production." Bulletin of Science, Technology \& Society no. 25 (4):361-371. doi: http://dx.doi.org/10.1177/0270467605277291.

Altieri, M. A. 2009. "Agroecology, Small Farms, and Food Sovereignty." Monthly Review-an Independent Socialist Magazine no. 61 (3):102-113. Available from $\mathrm{http} / / / \mathrm{www}$.doctoradoagroeco.org/wpcontent/uploads/2014/03/wk+9+Altieri+Agreocologysmall+farms+and+food+soverignity.pdf.

Altieri, M. A., F. R. Funes-Monzote, and P. Petersen. 2012. "Agroecologically efficient agricultural systems for smallholder farmers: contributions to food sovereignty." Agronomy for Sustainable Development no. 32 (1):113. doi: http://dx.doi.org/10.1007/s13593-011-0065-6.

Altieri, M. A., D. K. Letourneau, and J. R. Davis. 1983. "Developing Sustainable Agroecosystems." Bioscience no. 33 (1):45-49. doi: http://dx.doi.org/10.2307/1309244. 
Altieri, Miguel A. 2002. "Agroecology: the science of natural resource management for poor farmers in marginal environments." Agriculture, Ecosystems \& Environment no. 93 (1-3):1-24. doi: http://dx.doi.org/10.1016/s0167-8809(02)00085-3.

Arbuckle, K. E., and J. A. Downing. 2001. "The influence of watershed land use on lake $\mathrm{N}: \mathrm{P}$ in a predominantly agricultural landscape." Limnology and Oceanography no. 46 (4):970-975. doi: http://dx.doi.org/10.4319/lo.2001.46.4.0970.

Ayres, Ed. 2004. "The Hidden Shame of the Global Industrial Economy." World Watch no. 17 (1):20. Available from http://www.worldwatch.org/node/543.

Barnosky, A. D., E. A. Hadly, J. Bascompte, E. L. Berlow, J. H. Brown, M. Fortelius, W. M. Getz, J. Harte, A. Hastings, P. A. Marquet, N. D. Martinez, A. Mooers, P. Roopnarine, G. Vermeij, J. W. Williams, R. Gillespie, J. Kitzes, C. Marshall, N. Matzke, D. P. Mindell, E. Revilla, and A. B. Smith. 2012. "Approaching a state shift in Earth's biosphere." Nature no. 486 (7401):52-8. doi: http://dx.doi.org/10.1038/nature11018.

Benbrook, Charles M. 2012. "Impacts of genetically engineered crops on pesticide use in the U.S. -- the first sixteen years." Environmental Sciences Europe no. 24 (1):24. doi: http://dx.doi.org/10.1186/2190-4715-24-24.

Bennett, E. M., S. R. Carpenter, and N. F. Caraco. 2001. "Human impact on erodable phosphorus and eutrophication: A global perspective." Bioscience no. 51 (3):227-234. doi: http://dx.doi.org/10.1641/00063568(2001)051[0227:Hioepa]2.0.Co;2.

Biermann, F., K. Abbott, S. Andresen, K. Backstrand, S. Bernstein, M. M. Betsill, H. Bulkeley, B. Cashore, J. Clapp, C. Folke, A. Gupta, J. Gupta, P. M. Haas, A. Jordan, N. Kanie, T. Kluvankova-Oravska, L. Lebel, D. Liverman, J. Meadowcroft, R. B. Mitchell, P. Newell, S. Oberthur, L. Olsson, P. Pattberg, R. Sanchez-Rodriguez, H. Schroeder, A. Underdal, S. C. Vieira, C. Vogel, O. R. Young, A. Brock, and R. Zondervan. 2012. "Science and government. Navigating the anthropocene: improving Earth system governance." Science no. 335 (6074):1306-7. doi: http://dx.doi.org/10.1126/science.1217255. 
Bill No 54. Biotechnology Regulatory Authority of India Bill 2011 [cited 7/19/2012]. Available from http://indiagminfo.org/wpcontent/uploads/2011/09/BRAI_Bill_2011.pdf.

Bright, Chris 2003. "A History of Our Future." In State of the World 2003, edited by L. Starke. WW Norton \& Company. Available from http://globalchange.umich.edu/globalchange1/current/labs/Lab1_Challeng es/Challenges\%20We\%20Face\%202003.pdf.

Brown, L. R. 2011a. "Eroding Futures Why Healthy Soil Matters to Civilization." Futurist no. 45 (4):23-30. Available from http://futurethought.pbworks.com/w/file/fetch/46792746/2011WFS_Eroding-Futures_Why-Healthy-Soil-Matters-to-Civilization.pdf.

Brown, L. R. 2011b. World on the edge: How to prevent environmental and economic collapse. NY: WW Norton http://www.earthpolicy.org/books/wote/wotech9.

Carson, R. 1962. Silent Spring: Houghton Mifflin. Available from http://www.greenleaf-publishing.com/content/pdfs/top50_carson.pdf.

Chandrasekhar, C.P., and J. Ghosh. 2014. Consumption inequality in India. The Hindu Business Line. Available from http://www.thehindubusinessline.com/opinion/columns/c-pchandrasekhar/consumption-inequality-in-india/article3569657.ece.

Chapin III, F. S., E. S. Zavaleta, V. T. Eviner, R. L. Naylor, P. M. Vitousek, H. L. Reynolds, D. U. Hooper, S. Lavorel, O. E. Sala, S. E. Hobbie, M. C. Mack, and S. Diaz. 2000. "Consequences of changing biodiversity." Nature no. 405 (6783):234-242. doi: http://dx.doi.org/10.1038/35012241.

Coalition for a GM-Free India. Wrong Bill by the wrong people, for the wrong reasons - a critique by the Coalition for a GM-Free India 2012 [cited July 19, 2012]. Available from http://indiagminfo.org/wpcontent/uploads/2011/09/BRAI-critique-coalition-for-gm-free-india.pdf.

Cohen, J. E. 1995. "Population growth and earth's human carrying capacity." Science no. 269 (5222):341-6. Available from http://www.econ.yale.edu/ nordhaus/homepage/documents/CohenScience _carrying_cap_001.pdf. 
Cotula, L., and S. Vermeulen. 2009. "Deal or no deal: the outlook for agricultural land investment in Africa." International Affairs no. 85 (6):1233-+. doi: http://dx.doi.org/10.1111/j.1468-2346.2009.00859.x.

Davidson, C., H. B. Shaffer, and M. R. Jennings. 2002. "Spatial tests of the pesticide drift, habitat destruction, UV-B, and climate-change hypotheses for California amphibian declines." Conservation Biology no. 16 (6):15881601. doi: http://dx.doi.org/10.1046/j.1523-1739.2002.01030.x.

De Schutter, O. 2010. "Agroecology outperforms large-scale industrial farming for global food security." Press Release by the Special Rapporteur on the Right to Food in May. Available from http://www.ohchr.org/en/NewsEvents/Pages/DisplayNews.aspx?NewsID= $\underline{10178}$.

De Schutter, O. 2014. Report of the Special Rapporteur on the right to food. UN. Available from http://www.ohchr.org/EN/Issues/Food/Pages/FoodIndex.aspx.

Ehrlich, P. R., and E. Wilson. 1991. "Biodiversity studies: science and policy." Science no. 253 (5021):758-62. doi: http://dx.doi.org/10.1126/science.253.5021.758.

ETC Group. 2009. Who Will Feed Us. ETC Communiqué \#102. Available from http://www.etcgroup.org/content/who-will-feed-us.

Fedoroff, N. V., D. S. Battisti, R. N. Beachy, P. J. Cooper, D. A. Fischhoff, C. N. Hodges, V. C. Knauf, D. Lobell, B. J. Mazur, D. Molden, M. P. Reynolds, P. C. Ronald, M. W. Rosegrant, P. A. Sanchez, A. Vonshak, and J. K. Zhu. 2010. "Radically rethinking agriculture for the 21 st century." Science no. 327 (5967):833-4. doi: http://dx.doi.org/10.1126/science.1186834.

Food and Agriculture Organization of the United Nations (FAO). Aquastat Database. (2012)

Foster, J. B. 2007. "The ecology of destruction." Monthly Review-an Independent Socialist Magazine no. 58 (9):1-14. Available from http://monthlyreview.org/2007/02/01/the-ecology-of-destruction/. 
Frommel, A. Y., R. Maneja, D. Lowe, A. M. Malzahn, A. J. Geffen, A. Folkvord, U. Piatkowski, T. B. H. Reusch, and C. Clemmesen. 2012. "Severe tissue damage in Atlantic cod larvae under increasing ocean acidification."

Nature Climate Change no. 2 (1):42-46. doi: http://dx.doi.org/10.1038/Nclimate1324.

G8 Summit. 2009. L'Aquila Joint Statement on Global Food Security. Edited by L'Aquila Food Security Initiative. Available from http://www.g8italia2009.it/static/G8_Allegato/LAquila_Joint_Statement_o n_Global_Food_Security\%5B1\%5D,0.pdf.

Gall, Sandy. 2003a. "The Bushmen of the Kalahari." The Ecologist no. 33 (7):2731. Available from http://www.theecologist.org/investigations/politics_and_economics/26855 6/the_bushmen_of_the_kalahari.html

Gall, Sandy. 2003b. "Why are the Bushmen being evicted?" The Ecologist no. 33 (7):32-33. Available from http://go.galegroup.com/ps/i.do?id=GALE\%7CA108087354\&v=2.1\&u=ta

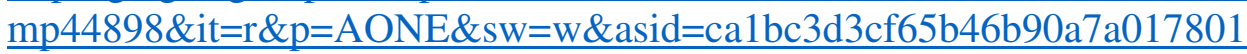
3acbc.

Ghoshal, S. 2005. "Bad management theories are destroying good management practices." Academy of Management Learning \& Education no. 4 (1):7591. doi: http://dx.doi.org/10.5465/AMLE.2005.16132558.

Gleick, P. H. 2000. "The changing water paradigm - A look at twenty-first century water resources development." Water International no. 25 (1):127-138. doi: http://dx.doi.org/10.1080/02508060008686804.

Griggs, D., M. Stafford-Smith, O. Gaffney, J Rockström, M. C. Ohman, P. Shyamsundar, W. Steffen, G. Glaser, N. Kanie, and I. Noble. 2013. "Policy: Sustainable development goals for people and planet." Nature no. 495 (7441):305-7. doi: http://dx.doi.org/10.1038/495305a.

Gurian-Sherman, D. 2009. Failure to Yield. Cambridge, MA. Available from http://www.ucsusa.org/sites/default/files/legacy/assets/documents/food_an d_agriculture/failure-to-yield.pdf. 
Hansen, J., Pushker K., Makiko S., Frank Ackerman, Paul J. Hearty, Ove HoeghGuldberg, Shi-Ling Hsu, Fred Krueger, Camille Parmesan, J Rockström, Eelco J. Rohling, Jeffrey Sachs, Pete Smith, Konrad Steffen, Lise Van Susteren, Karina von Schuckmann, and James C. Zachos. 2012. Scientific Case for Avoiding Dangerous Climate Change to Protect Young People and Nature. Eugene, Oregon Our Children's Trust. Available from http://arxiv.org/ftp/arxiv/papers/1110/1110.1365.pdf.

Hansen, J., D. Rind, A. Delgenio, A. Lacis, S. Lebedeff, M. Prather, and R. Ruedy. 1991. "Regional greenhouse climate effects." In Greenhouse-GasInduced Climate Change: a Critical Appraisal of Simulations and Observations, edited by Schlesinger ME, 211-229. Amsterdam: Elsevier. Available from http://digitalcollections.library.cmu.edu/awweb/awarchive?type=file\&item $=437940$.

Hansen, J., M. Sato, and R. Ruedy. 2012. "Perception of climate change." Proc Natl Acad Sci U S A no. 109 (37):E2415-23. doi: http://dx.doi.org/10.1073/pnas.1205276109.

Holden, C. 1992. "Scientists' campaign to save Earth." Science no. 258 (5087):1433. doi: http://dx.doi.org/10.1126/science.258.5087.1433.

Hole, D. G., A. J. Perkins, J. D. Wilson, I. H. Alexander, P. V. Grice, and A. D. Evans. 2005. "Does organic farming benefit biodiversity?" Biological Conservation no. 122 (1):113-130. doi: http://dx.doi.org/10.1016/j.biocon.2004.07.018.

Holt Gimenez, E., and A. Shattuck. 2011. "Food crises, food regimes and food movements: rumblings of reform or tides of transformation?" J Peasant Stud no. 38 (1):109-44. doi: http://dx.doi.org/10.1080/03066150.2010.538578.

Horrigan, L., R. S. Lawrence, and P. Walker. 2002. "How sustainable agriculture can address the environmental and human health harms of industrial agriculture." Environmental Health Perspectives no. 110 (5):445-456. doi: http://dx.doi.org/PMC1240832.

Howard, P. 2009. "Visualizing Consolidation in the Global Seed Industry: 19962008." Sustainability no. 1 (4):1266-1287. doi: http://dx.doi.org/10.3390/su1041266. 
IAASTD. 2009. Agriculture Crossroads, IAASTD Synthesis Report. edited by Beverly D. McIntyre, Hans R. Herren, Judi Wakhungu and Robert T. Watson. Washington, DC: International Assessment of Agricultural Knowledge, Science and Technology for Development http://apps.unep.org/publications/pmtdocuments/Agriculture\%20at\%20a\%20crossroads\%20-\%20Synthesis\%20report2009Agriculture_at_Crossroads_Synthesis_Report.pdf.

IPCC, 2014: Climate Change 2014: Synthesis Report: The Physical Science Basis. edited by Coordinating Lead Authors, Thomas Stocker, Qin Dahe and Gian-Kasper Plattner. Geneva, Switzerland: IPCC. Available from https://www.ipcc.ch/pdf/assessmentreport/ar5/wg1/WG1AR5_ALL_FINAL.pdf

Irwin, Aisling. Scientists criticise lack of urgency in Rio+20 accord. SciDev.Net, 6/25/2012 [cited 7/25/2012]. Available from http://www.scidev.net/en/science-and-innovation-policy/science-at-rio20/news/scientists-criticise-lack-of-urgency-in-rio-20-accord.html.

Jamison, D. T., J. G. Breman, Anthony R. Measham, George Alleyne, Mariam Claeson, David B. Evans, Prabhat Jha, Anne Mills, and Philip Musgrove. 2006. Disease Control Priorities in Developing Countries. New York NY: Oxford University Press. Available from http://www.ncbi.nlm.nih.gov/books/NBK11728/.

Jayaraman, K. 2010. "Bt brinjal splits Indian cabinet." Nature Biotechnology no. 28:296 doi: http://dx.doi.org/10.1038/nbt0410-296.

Keilman, N. 2001. "Demography. Uncertain population forecasts." Nature no. 412 (6846):490-1. doi: http://dx.doi.org/10.1038/35087685.

Kennedy, R., and T. Worcester. 2004. "Snouts in the trough." The Ecologist no. 33 (10):50-53. Available from http://eds.b.ebscohost.com/ehost/pdfviewer/pdfviewer?vid=9\&sid=1e845a ab-5733-4fe3-a37d-ef6ff666087b\%40sessionmgr111\&hid=104.

Kerr, R. B. 2012. "Lessons from the old Green Revolution for the new: Social, environmental and nutritional issues for agricultural change in Africa." Progress in Development Studies no. 12 (2-3):213-229. doi: http://dx.doi.org/10.1177/146499341101200308. 
Kirby, David. 2010. The Animal Factory: The Looming Threat of Industrial Pig, Dairy, and Poultry Farms to Humans and the Environment: St. Martin's Press. Available from http://us.macmillan.com/animalfactory/davidkirby.

Klein, N. 2001. "Reclaiming the commons." new left review no. 9 (9):81-89. Available from http://newleftreview.org/II/9/naomi-klein-reclaiming-thecommons.

Klein, Naomi. 2014. This changes everything: capitalism vs. the climate: Simon and Schuster.

Klinger, D., and R. Naylor. 2012. "Searching for Solutions in Aquaculture: Charting a Sustainable Course." Annual Review of Environment and Resources, Vol 37 no. 37 (1):247-+. doi: http://dx.doi.org/10.1146/annurev-environ-021111-161531.

Leach, M., J. Rockström, P. Raskin, I. Scoones, A. C. Stirling, A. Smith, J. Thompson, E. Millstone, A. Ely, E. Arond, C. Folke, and P. Olsson. 2012. "Transforming Innovation for Sustainability." Ecology and Society no. 17 (2). doi: http://dx.doi.org/10.5751/Es-04933-170211.

Lindley, Mary. 1976. "Pesticides and the environment." Nature no. 263 (5577):464-464. doi: http://dx.doi.org/10.1038/263464a0.

MacDonald, Mia 2012. "Food Security and Equity in a Climate-Constrained World." In State of the World 2011: Innovations That Nourish the Planet, edited by L. Starke. WW Norton \& Company. Available from http://www.worldwatch.org/system/files/SOW12\%20Summary\%20(Chapt er\%2014).pdf.

MacDonald, Mia , and Danielle Nierenberg. 2003. "Linking Population,Women, and Biodiversity " In State of the World 2003, edited by L. Starke. WW Norton \& Company http://www.worldwatch.org/node/3614.

Mallin, M. A. 2000. "Impacts of industrial animal production on rivers and estuaries." American Scientist no. 88 (1):26-37. doi: http://dx.doi.org/10.1511/2000.15.762.

Marmot, Michael. 2014. "Capital health." The Lancet no. 384 (9941):394-395. doi: http://dx.doi.org/10.1016/s0140-6736(14)61263-0. 
McGinn, A. P. 2002. "Reducing Our Toxic Burden." In State of the World 2002: The Worldwatch Institute Report, edited by Christopher Flavin and Linda Starke, 75-100. New York: The Worldwatch Institute W.W. Norton \& Co. Available from http://www.worldwatch.org/node/3623.

McKibben, B. 2012. "Global Warming's Terrifying New Math." Rolling Stone (1162). Available from http://www.rollingstone.com/politics/news/globalwarmings-terrifying-new-math-20120719.

Mikhail, Monique. 2012. "Growing a Sustainable Future." In State of the World 2012: Moving Toward Sustainable Prosperity, edited by Linda Starke. Island Press/Center for Resource Economics. Available from http://www.worldwatch.org/system/files/SOW12\%20Summary\%20(Chapt er\%2013).pdf.

Montgomery, D. R. 2007. "Soil erosion and agricultural sustainability." Proc Natl Acad Sci U S A no. 104 (33):13268-72. doi: http://dx.doi.org/10.1073/pnas.0611508104.

Monsanto Company. "Improving Agriculture" entry. Company website. 20022013. Retrieved Sunday, 12/16/2012. http://www.monsanto.com/improvingagriculture/pages/our-role.aspx

—. "Stock Performance" entry. Web. 2015. Retrieved 12/16/2012. http://www.monsanto.com/investors/Pages/stock-performance.aspx

Moyers, B., and C. Hedges. How Whole Regions of America Have Been Destroyed in the Name of Quarterly Profits 2012 [cited 7/22/2012]. Available from http://billmoyers.com/segment/chris-hedges-oncapitalism\%E2\%80\%99s-\%E2\%80\%98sacrifice-zones\%E2\%80\%99/

Myers, R. A., and B. Worm. 2003. "Rapid worldwide depletion of predatory fish communities." Nature no. 423 (6937):280-3. doi: http://dx.doi.org/10.1038/nature01610.

O'Donnell, C. St. Pete drafting regulations to allow small urban farms. Tampa Media Group, LLC 2014. Available from http://tbo.com/pinellascounty/st-pete-drafting-regulations--to-allow-small-urban-farms$\underline{\mathrm{b} 82501046 \mathrm{z} 1}$ 
O'Reilly, K., D. Paper, and S. Marx. 2012. "Demystifying Grounded Theory for Business Research." Organizational Research Methods no. 15 (2):247262. doi: http://dx.doi.org/10.1177/1094428111434559.

Office of the Press Secretary. 2012. Fact Sheet: G-8 Action on Food Security and Nutrition. edited by The White House. Washington, DC https://www.whitehouse.gov/the-press-office/2012/05/18/fact-sheet-g-8action-food-security-and-nutrition.

Pearce, F. 2011. "Dubious assumptions prime population bomb." Nature no. 473 (7346):125. doi: http://dx.doi.org/10.1038/473125a.

Piketty, Thomas, and Arthur Goldhammer. 2014. Capital in the twenty-first century: Belknap Press http://piketty.pse.ens.fr/en/capital21c2.

Piketty, Thomas, and Emmanuel Saez. 2014. "Inequality in the long run." Science no. 344 (6186):838-843 doi: http://dx.doi.org/10.1126/science.1251936.

Pimentel, D., C. Harvey, P. Resosudarmo, K. Sinclair, D. Kurz, M. McNair, S. Crist, L. Shpritz, L. Fitton, R. Saffouri, and R. Blair. 1995. "Environmental and economic costs of soil erosion and conservation benefits." Science no. 267 (5201):1117-23. doi: http://dx.doi.org/10.1126/science.267.5201.1117.

Renner, Michael. 2012. "Making the Green Economy Work for Everybody." In State of the World 2012: Moving Toward Sustainable Prosperity, edited by Linda Starke. Island Press/Center for Resource Economics. http://www.worldwatch.org/system/files/SOW12\%20Summary\%20(Chapt er\%201).pdf.

Rio Occupy Working Groups. 2012. People's Petition. (7/19/2012), https://panworldwide.wordpress.com/2012/06/04/occupy-earth-summitcommon-statement/.

Rockström, J, W. Steffen, K. Noone, A. Persson, F. S. Chapin, 3rd, E. F. Lambin, T. M. Lenton, M. Scheffer, C. Folke, H. J. Schellnhuber, B. Nykvist, C. A. de Wit, T. Hughes, S. van der Leeuw, H. Rodhe, S. Sorlin, P. K. Snyder, R. Costanza, U. Svedin, M. Falkenmark, L. Karlberg, R. W. Corell, V. J. Fabry, J. Hansen, B. Walker, D. Liverman, K. Richardson, P. Crutzen, and J. A. Foley. 2009a. "A safe operating space for humanity." Nature. No. 461 (7263):472-5. doi: http://dx.doi.org/10.1038/461472a. 
Rockström, J, W. Steffen, K. Noone, A. Persson, F. S. Chapin, E. Lambin, T. M. Lenton, M. Scheffer, C. Folke, H. J. Schellnhuber, B. Nykvist, C. A. de Wit, T. Hughes, S. van der Leeuw, H. Rodhe, S. Sorlin, P. K. Snyder, R. Costanza, U. Svedin, M. Falkenmark, L. Karlberg, R. W. Corell, V. J. Fabry, J. Hansen, B. Walker, D. Liverman, K. Richardson, P. Crutzen, and J. Foley. 2009b. "Planetary Boundaries: Exploring the Safe Operating Space for Humanity." Ecology and Society no. 14 (2). doi: http://pdxscholar.library.pdx.edu/iss_pub/64/.

Rosset, P. 2011. "Food Sovereignty and Alternative Paradigms to Confront Land Grabbing and the Food and Climate Crises." Development no. 54 (1):2130. doi: http://dx.doi.org/10.1057/dev.2010.102.

Royal Society and National Academy of Sciences statement. Joint Statement of the Royal Society of London and the US National Academy of Sciences. Resource Management and a Sustainable World. 1992. Retrieved Monday, 7/23/2012. Available from http://www.jayhanson.us/page7.htm.

Sheets, Connor Adams. 2013. "'Monsanto Protection Act': 5 Terrifying Things To Know About The HR 933 Provision." International Business Times http://www.ibtimes.com/monsanto-protection-act-5-terrifying-thingsknow-about-hr-933-provision-1156079.

Souza, Pete. "The G8 Summit at Camp David." The White House Photo Gallery. 2012. Retrieved Monday, 5/11/2015. https://www.whitehouse.gov/photosand-video/photogallery/g8-summit-camp-david

Spinks, R. 2011. " How India squared up to Monsanto's 'biopiracy'." The Ecologist no. 12th October, 2011. Available from http://www.theecologist.org/News/news_analysis/1087730/how_india_squ ared_up_to_monsantos_biopiracy.html

Stehr, Nico. 2014. "Climate policy: A societal sea change." Nature no. 513 (7518):312-312. doi: http://dx.doi.org/10.1038/513312a.

Stern, P. C. 1993. "A second environmental science: human-environment interactions." Science no. 260 (5116):1897-9. doi: http://dx.doi.org/10.1126/science.260.5116.1897. 
Tanmay, D. Genetically Modified Foods-The Rights of the General Public, November 19, 2011 2011. Available from http://dx.doi.org/10.2139/ssrn.1967927.

Teka, Kassa, Anton Van Rompaey, and Jean Poesen. 2013. "Assessing the role of policies on land use change and agricultural development since 1960s in northern Ethiopia." Land Use Policy no. 30 (1):944-951. doi: http://dx.doi.org/10.1016/j.landusepol.2012.07.005.

Tollefson, J., and N. Gilbert. 2012. "Earth summit: Rio report card." Nature no. 486 (7401):20-3. doi: http://dx.doi.org/10.1038/486020a.

Tscharntke, T., A. M. Klein, A. Kruess, I. Steffan-Dewenter, and C. Thies. 2005. "Landscape perspectives on agricultural intensification and biodiversity ecosystem service management." Ecology Letters no. 8 (8):857-874. doi: http://dx.doi.org/10.1111/j.1461-0248.2005.00782.x.

Turner, R. E., and N. N. Rabalais. 2003. "Linking landscape and water quality in the Mississippi river basin for 200 years." Bioscience no. 53 (6):563-572. doi: http://dx.doi.org/10.1641/00063568(2003)053[0563:Llawqi]2.0.Co;2.

UNEP. 2012. Global Environment Outlook \#5. Valletta, Malta: United Nations Environment Programme. Available from http://www.unep.org/geo/pdfs/geo5/GEO5_report_full_en.pdf.

Union of Concerned Scientists. Monday, July 23, 2012. World Scientists' Warning to Humanity Scientist Statement. Union of Concerned Scientists 1992Monday, July 23, 2012]. Available from http://www.ucsusa.org/about/1992-world-scientists.html.

United Nations. 1992a. Agenda 21. In A/CONF.151/26 (Vol. I). Rio De Janeiro, Brazil: Conference on Environment and Development. http://www.un.org/documents/ga/conf151/aconf15126-1.htm.

United Nations. 1992b. Rio Declaration on Environment and Development. In A/CONF.151/26. Rio de Janeiro, Brazil: http://www.un.org/documents/ga/conf151/aconf15126-1annex1.htm.

United Nations. 2000. Millennium Declaration. A/RES/55/2, http://www.un.org/millennium/declaration/ares552e.htm. 
United Nations. 2002. Johannesburg Declaration on Sustainable Development. World Summit on Sustainable Development, http://www.undocuments.net/jburgdec.htm.

United Nations. 2012. The future we want. A/CONF.216//L.1 (June 2012), https://rio20.un.org/sites/rio20.un.org/files/a-conf.2161-1_english.pdf.pdf.

Vallianatos, Evaggelos G. 2014. Poison Spring: The Secret History of Pollution and the EPA: Bloomsbury Publishing USA http://bloomsbury.com/us/poison-spring-9781608199143/.

von Braun, J. 2010. "Strategic body needed to beat food crises." Nature no. 465 (7298):548-9. doi: http://dx.doi.org/10.1038/465548a.

Watson, T. 1992. "Petition Warns of Pending Global Environmental Crisis." Nature no. 360 (6401):200-200. doi: http://dx.doi.org/10.1038/360200a0.

WCED. 1987. Our Common Future. http://www.un-documents.net/our-commonfuture.pdf.

Worm, B., E. B. Barbier, N. Beaumont, J. E. Duffy, C. Folke, B. S. Halpern, J. B. Jackson, H. K. Lotze, F. Micheli, S. R. Palumbi, E. Sala, K. A. Selkoe, J. J. Stachowicz, and R. Watson. 2006. "Impacts of biodiversity loss on ocean ecosystem services." Science no. 314 (5800):787-90. doi: http://dx.doi.org/10.1126/science.1132294.

Zoysa, Uchita de Peoples' Sustainability Treaties 2012 [cited 7/19/2012]. Available from http://sustainabilitytreaties.org/pst-manifesto/ 